\title{
SYMPHYOTRICHUM CILIATUM AN INVASIVE SPECIES IN THE ROMANIAN FLORA - CONTRIBUTIONS TO THE KNOWLEDGE OF THE VEGETATIVE ORGANS STRUCTURE
}

\begin{abstract}
SÂRBU Anca ${ }^{1 *}$, SMARANDACHE Daniela ${ }^{1}$
Abstract: Symphyotrichum ciliatum (Ledeb.) G.L. Nesom is an adventive plant first reported in Romania in 1967, which has spread rapidly over the last few decades in Moldova, Muntenia and, more recently, in Transylvania. Although the species has been known for a while in Europe and Romania, there is no information about the anatomy of the vegetative organs of this invasive taxon. This paper presents a series of structural aspects of the vegetative body, of Symphyotrichum ciliatum collected from a sandy and salty substrate (Sacalin Island - Danube Delta). These demonstrate the ability of this plant to adapt to the environment and its capacity to achieve a wide spread. As such, although this plant is an annual species, the root and stem achieve secondary growth in their width, which offers robustness to the corm; the palisade tissue has an ecvifacial disposition which enhances efficiency in capturing light, especially on sandy soil that reflects light; there are aeriferous and aquiferous formations that ensure efficiency in adapting to a wet and relatively salty environment. These results are documented by original photographs of optical microscopy and a distribution map of the taxon in Romania as at 2011.
\end{abstract}

Keywords: adventive plant, meso-hygro-halophyte, structural adaptations

\section{Introduction}

Symphyotrichum ciliatum (Lebed.) G.L. Nesom [Brachyactis ciliata (Ledeb.) Ledeb., Erigeron ciliatus Ledeb.] (Fam. Asteraceae) (Sârbu et al. 2013) is an adventive, invasive plant (Anastasiu \& Negrean 2007, Sîrbu \& Oprea 2011) reported in Romania in 1967 at Şesul Bahlului (Iaşi County) and at Tanacu (Vaslui County) (Beldie \& Váczy 1976).

It is an annual herbaceous plant, with erect stems and branched at the bases (up to $60 \mathrm{~cm}$ height), yellow-green, frequently with a hint of red, glabrous or with sparse hairs.

Leaves are alternate, simple, sessile, linear or linear-lanceolates. The edge of the lamina is whole and has short tector hairs (ciliated edge - 'ciliatum') and the top is short acuminate. The base leaves usually dry before flowering (Fig. 1).

The plant flowers between August and October, forming numerous heads (calathides), displayed in panicles. Fruits with pappus are easily transported over long distances.

Heliophile, thermophile, eurinitrophile species, it prefers slightly acidic to neutral soils. It grows in relatively wet places (meso-hydrophyte) and more or less

\footnotetext{
${ }^{1}$ University of Bucharest, Faculty of Biology, Department of Botany \& Microbiology, 1-3 Intr. Portocalelor, Sector 5, 060101 - Bucureşti, Romania, e-mail address: anchusa24@yahoo.com
} 
saline (halophyte), on silt meadows, marshes, disturbed land, along canals and ditches, along roads, train stations, ruderal places, in plains and hills floors (Popescu \& Sanda 1998, Sârbu et al. 2001, Ciocârlan 2009, Sîrbu \& Oprea 2011, Sârbu et al. 2013).

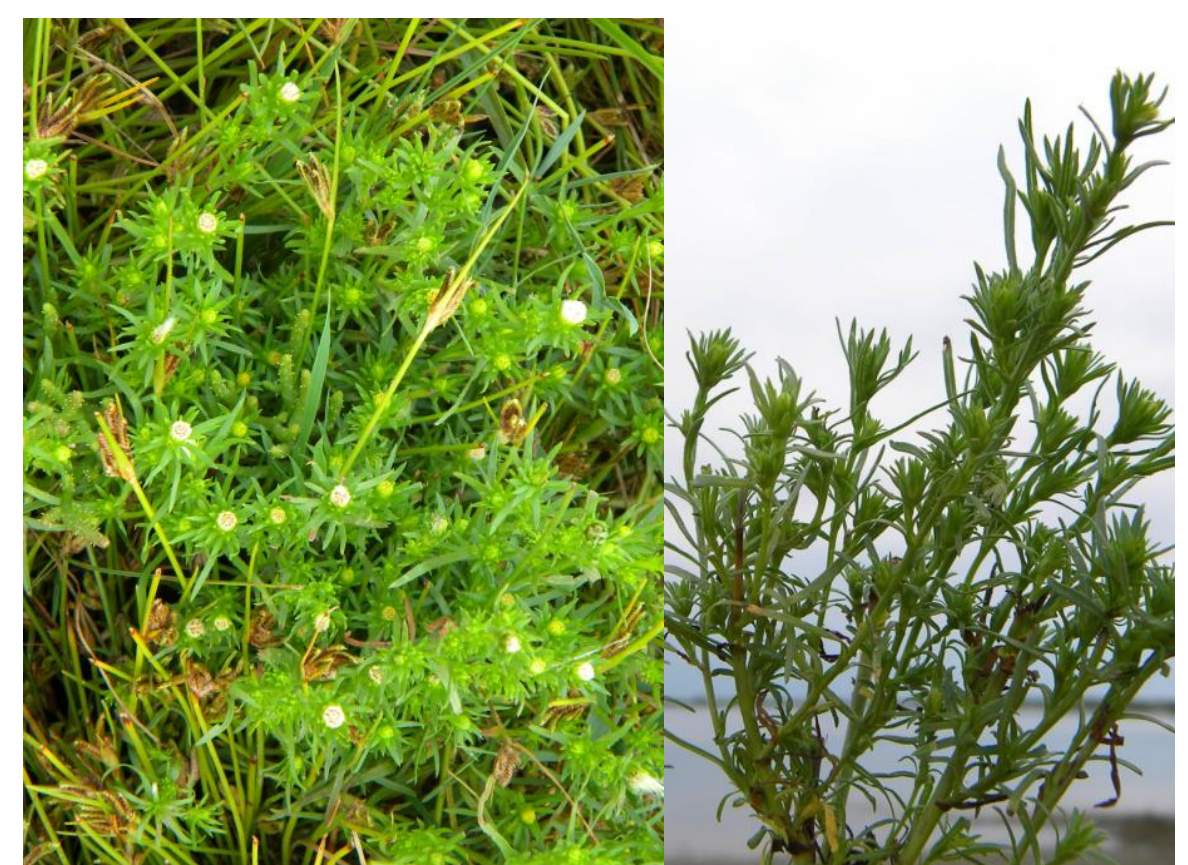

Fig. 1. Symphyotrichum ciliatum, the Sacalin Island - Danube Delta, September 2012

(Photo: Daniela Smarandache)

It is worth pointing out that ,the plant can vegetate on dry soils, but it prefers soils with excess moisture and moderate in salt" (Filipaş \& Cristea 2006).

The natural range of the species is in Asia (Sârbu et al. 2013), but according to other authors its range also includes North America (Sîrbu \& Oprea 2011).

Symphyotrichum ciliatum is recorded as being native to North America and the steppes of North Eurasia and present in the salt marshes (Sîrbu et al. 2015).

In the USA the plant is common in areas with degraded land, especially along motorways, where salt spread during the cold season accumulates. Occasionally the species grows in industrial area, in areas where waste is stored and along roads crossed by lorries (McKinney 2006).

As an adventive plant in Europe, it has been mentioned in Poland, the Republic of Moldova and Romania (Sîrbu \& Oprea 2011). As regards its presence in Europe, the taxon was reported in 1987 at Košice, being identified as ,,a new species in the flora of Czechoslovakia”. It was envisaged at that time that ,given the ecological necessities of the species, the taxon will spread in the communities of ruderal and coastal plants, and eventually in the agrocenoses from the plain regions in Eastern Slovakia" (Chocholoušková \& Pyšek 2003). 
Since 1967 the plant has spread relatively quickly in Romania, having been reported in localities from Moldova (Iaşi, Botoşani, Suceava, Neamţ, Vaslui, Galaţi and Vrancea counties), Muntenia (Buzău County), Dobrogea (including the Danube Delta) and, more recently, from Transylvania (Sibiu, Harghita, Cluj - Cluj-Napoca counties) (Sîrbu \& Oprea 2011, Filipaş \& Cristea 2006, Sîrbu et al. 2015) (Fig. 2).

In Muntenia (Buzău County) the taxon was initially reported along the river Râmnicul Sărat (Ştefan 1980). Subsequently the presence of the species was noted in two other locations from Buzău County: Cocârceni village - the basin of the river Bălăneasa, a tributary of the river Buzău, at an altitude of 300 meters, on gravel and sandy places, and also in the village Vipereşti, in ruderal places (Anastasiu 2010).

As regards the presence of the taxon in the Danube Delta, this was reported in the Sacalin Island, Sf. Gheorghe (Ciocârlan 1994, 2009). Up to 2011, Symphyotrichum ciliatum was reported in Romanian in 86 locations from 13 counties.

Taking into account the plant's capacity to develop abundantly and its ecological preferences, the plant is considered particularly dangerous because it can invade mesohydrophilic and moderately halophilic areas in coastal habitats, which are considered a priority in the strategy for biodiversity conservation (Filipaş \& Cristea 2006).

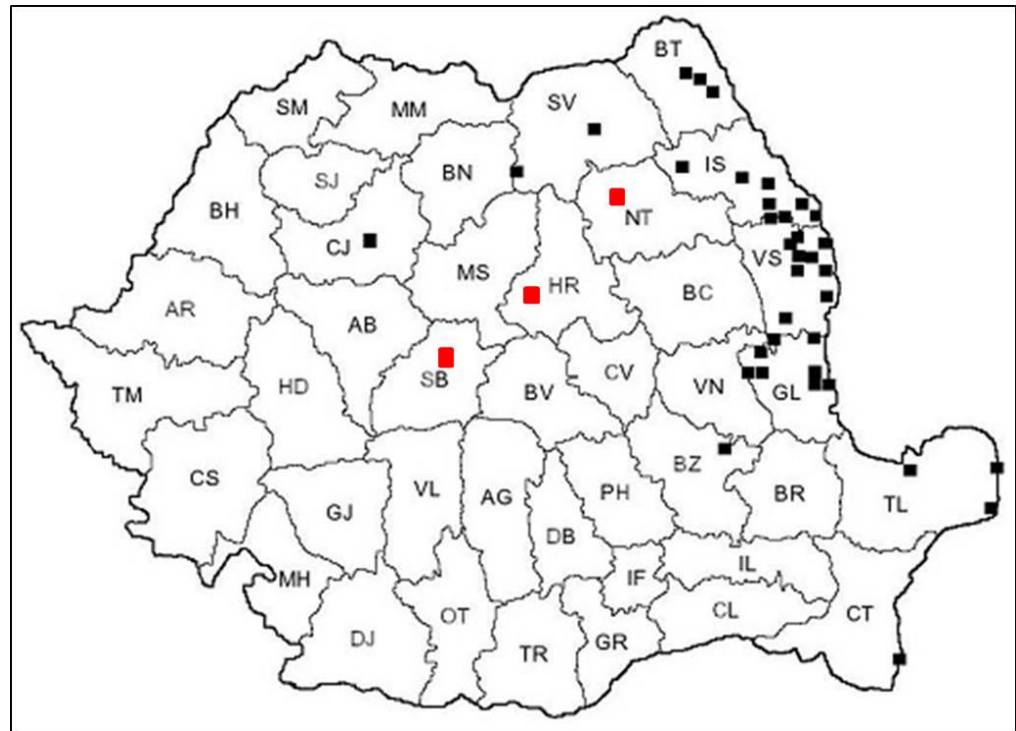

Fig. 2. Symphyotrichum ciliatum, distribution in Romania, according to Filipaş and Cristea 2006, with additions according to Sîrbu and Oprea 2011

(additions after 2006 in red)

\section{Material and methods}

The biological material represented by mature plants of $20-25 \mathrm{~cm}$ height, at fructification, was collected in September 2012 in the Danube Delta, Sf. Gheorghe locality, the Sacalin Island, during field trips made within the framework of the project "Complex study on allochthonous plants from Danube Delta in order to establish their 
ecological impact, to assess the risk and to elaborate minimal measures for management" (grant PN-II-ID-PCE, contract no. 970/2009).

The fixing of the biological material was made in $70 \%$ ethanol for a period of one year. In order to conduct structural analyses, cross sections were made through the principal root (median third), principal stem (lower, median and superior third), Order I branch (lower, median and superior) and lamina (median third).

The sections obtained were processed according to the double colouration technique (Iodine Green \& Carmine Alum), and the highlighting of starch was carried out with IIK (Şerbănescu-Jitariu et al. 1983).

The analysis of the microscopic slides and their micro-photography was made with the Docuval optical microscope.

\section{Results and discussion}

The root. The root differentiates a secondary structure which has resulted from the activity of both primary meristems: the cambium and phellogen (Fig. 3).

The phellogen is sub-epidermal, has a reduced activity and produces a few layers of suber, which exfoliate gradually, and a few layers of phelloderm (Fig. 4).

The primary bark is parenchymatous (aeriferous parenchyma), with large cells, between which there are meatuses and aeriferous gaps (Figs 3,4).

The cortical zone ends with a primary type endodermis, with tangentially elongated cells and with Caspary thickening in the radial walls. The cells of this last stratum of the bark are in contact with the pericycle and have a regular disposition along the entire circumference of the root (Fig. 4).

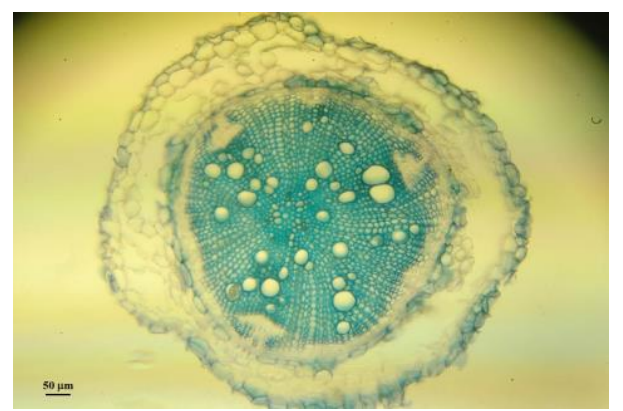

Fig. 3. Symphyotrichum ciliatum, the structure of the root in the median area (cross section, Iodine Greene \& Carmine Alum)

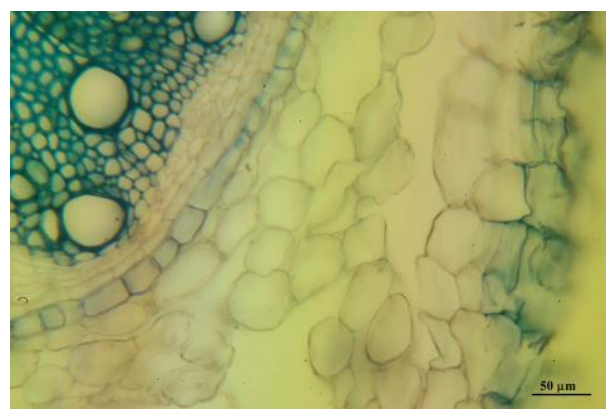

Fig. 4. Symphyotrichum ciliatum, cross section through the root, highlighting the suber, the bark and the external area of the central cylinder (Iodine Greene \& Carmine Alum)

The central cylinder is bulky ( $70 \%$ of the root). The pericycle is unistratified with tangentially elongated cells which generally alternate with the cells of the endodermis (Figs 4, 5). 
The secondary vascular tissues are unequally represented in the structure of the root. The secondary phloem is in the form of a narrow ring which includes from place to place packages of sclerenchymatous fibres. The sclerenchymatous fibres have relatively thin and heavily lignified cell walls (Fig. 6).

The secondary xylem is located centrally and has the form of a bulky and compact body. The wood vessels have a different diameter and are dispersed in a mass of libriform (the fibres have heavily thickened and lignified walls) (Fig. 7).

The primary xylem is located centrally and the pith is missing (Fig. 7).

In the structure of the central cylinder there are uni- and pluristratified medullary rays, whose cells highlight uniformly thickened and lignified cell wall (Fig. 7).
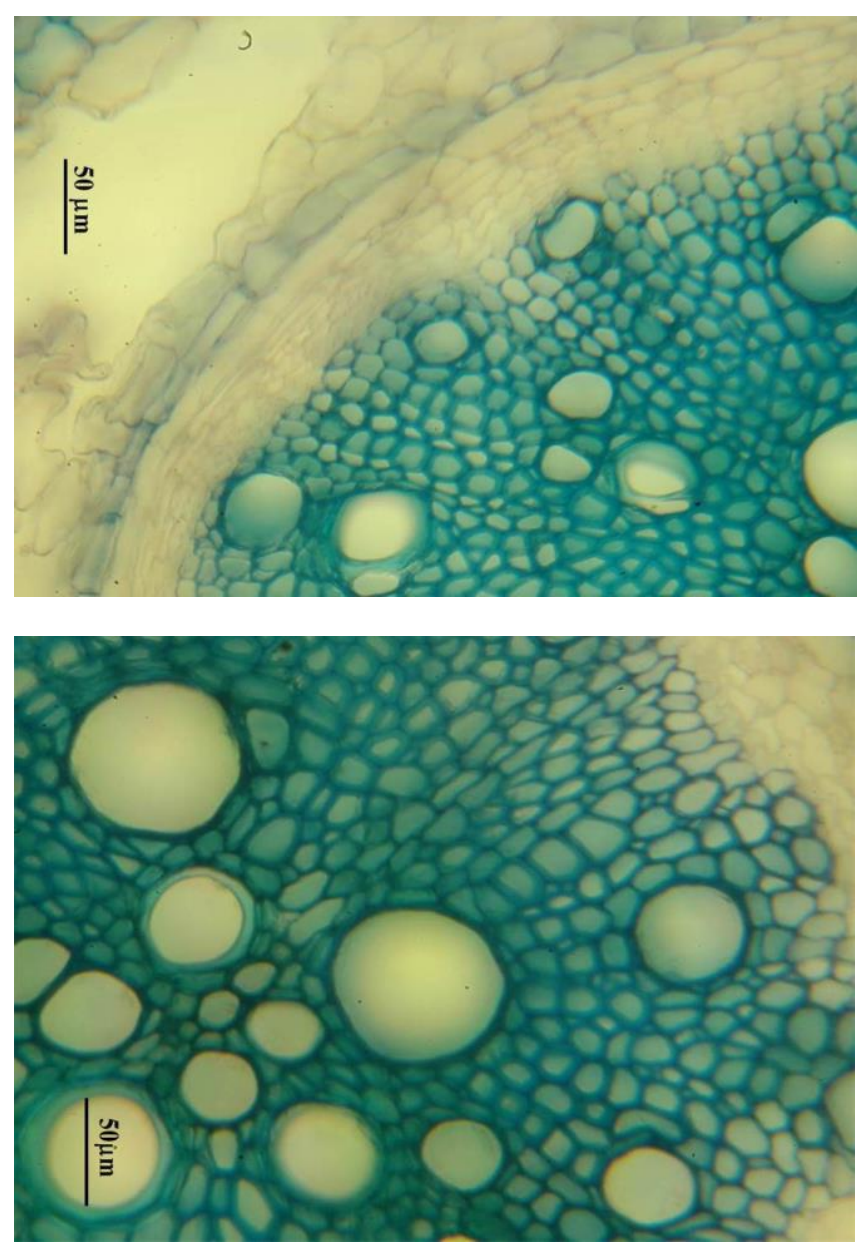

Fig. 5. Symphyotrichum ciliatum, cross section through the root highlighting the central cylinder (Iodine Greene \& Carmine Alum)

Fig. 6. Symphyotrichum ciliatum, cross section through the root highlighting elements of the central cylinder (Iodine Greene \& Carmine Alum) 


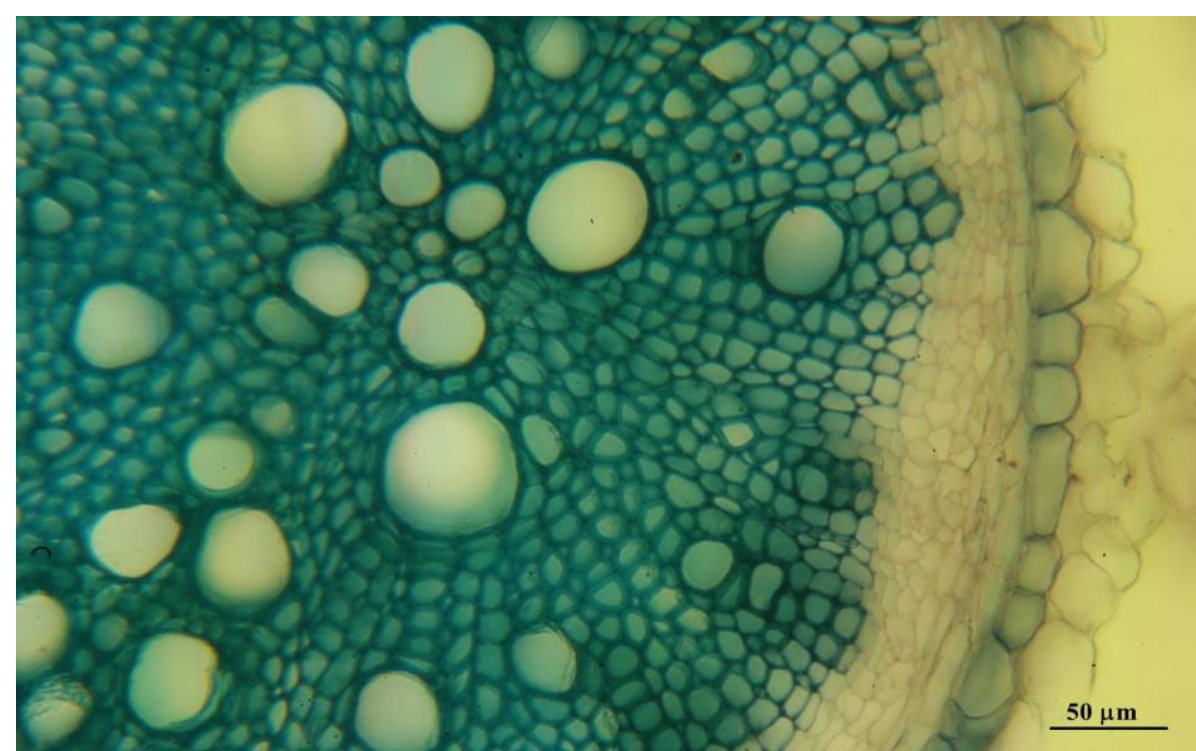

Fig. 7. Symphyotrichum ciliatum, cross section through the root highlighting the compact body of the xylem (Iodine Greene \& Carmine Alum)

The stem. The structure is typical secondary at all three levels of sectioning (lower, median and upper third) and only results from the activity of the vascular cambium. The epidermis is unistratified and covered by a noticeable cuticle which differentiates cuticular ridges. The stomata are anomocytic and rare. In the lower third of the stem the bark is represented by an aerenchyma with large, relatively isodiametric cells with meatuses and gaps (Fig. 8). In the median third and the upper third respectively, the dimensions of the bark and those of the aeriferous gaps are reduced. The internal layer of the bark forms an endodermis where no accumulation of starch was found (reaction with IIK) (Figs 8, 9, 10).

Inside the central cylinder, the vascular tissues are displayed in the form of concentric rings (Fig. 9). The cambium produces a thin external area of phloem and an internal thick area of xylem. Both rings of secondary tissues are crossed by medullary rays of different thickness, made of cells with uniformly thickened and lignified walls (Figs 9, 10).

At the external limit of the secondary phloem there are packages of sclerenchymatous fibres. The sclerenchymatous cells have heavily thickened and lignified walls (Figs 9, 10).

In the secondary xylem the wood fibres (libriform) are predominant and feature radial rows of wood vessels of different sizes. Both the elements of the secondary xylem and the wood fibres have lignified cells wall.

At the internal part of the secondary xylem, the primary xylem can be observed. This is formed of wood vessels displayed in packages and separated by parenchymatous cells, with walls slightly thickened and lignified (Fig. 9). 
The pith is parenchymatous in the lower third (Fig. 9). In the median and upper thirds the cells formed in the central area of the pith disorganise and thus lead to the creation of two large aeriferous cavities with an irregular contour (Figs 11, 12).

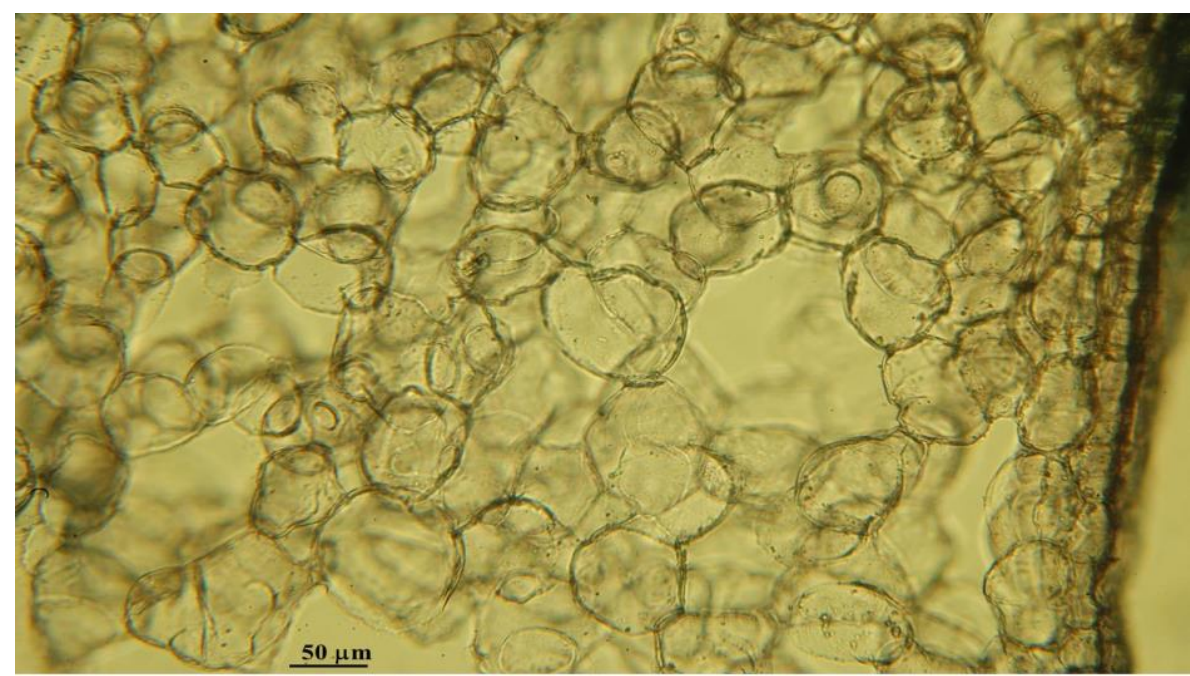

Fig. 8. Symphyotrichum ciliatum, cross section through the base area of the stem highlighting the epidermis and the cortical aerenchyma (Iodine Greene \& Carmine Alum, reaction with IIK)

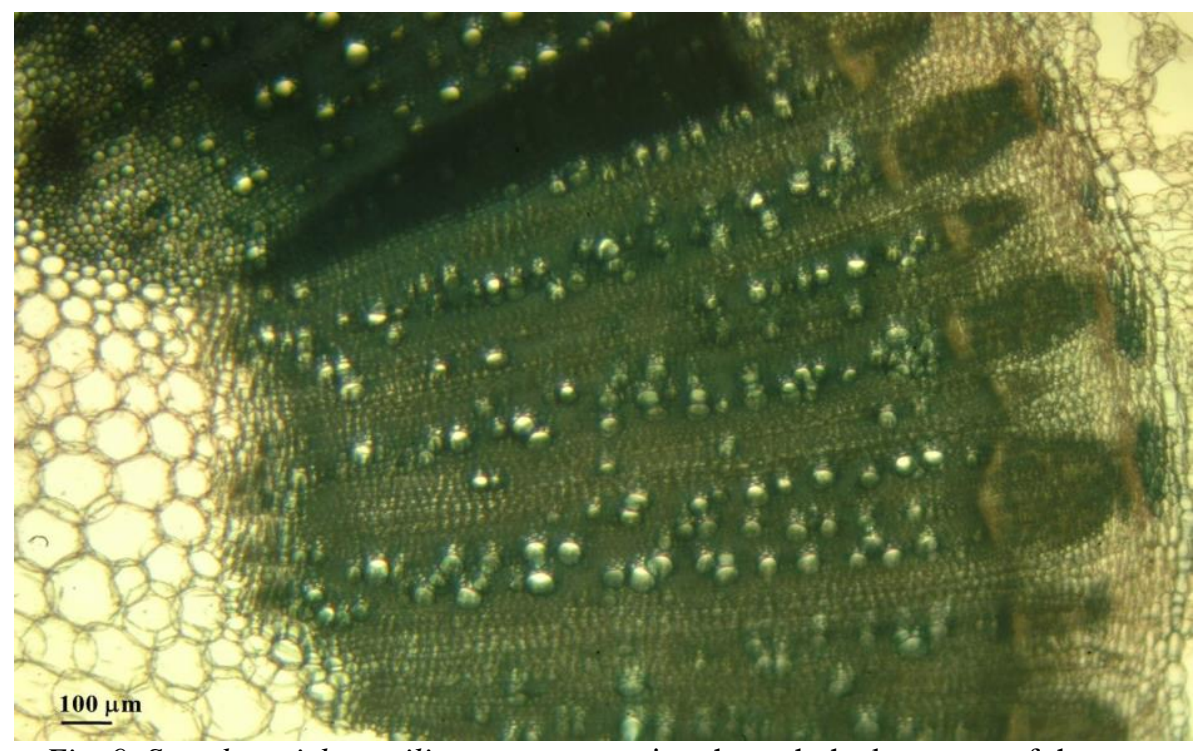

Fig. 9. Symphyotrichum ciliatum, cross section through the base area of the stem highlighting vascular tissues and the pith (Iodine Greene \& Carmine Alum, reaction with IIK) 


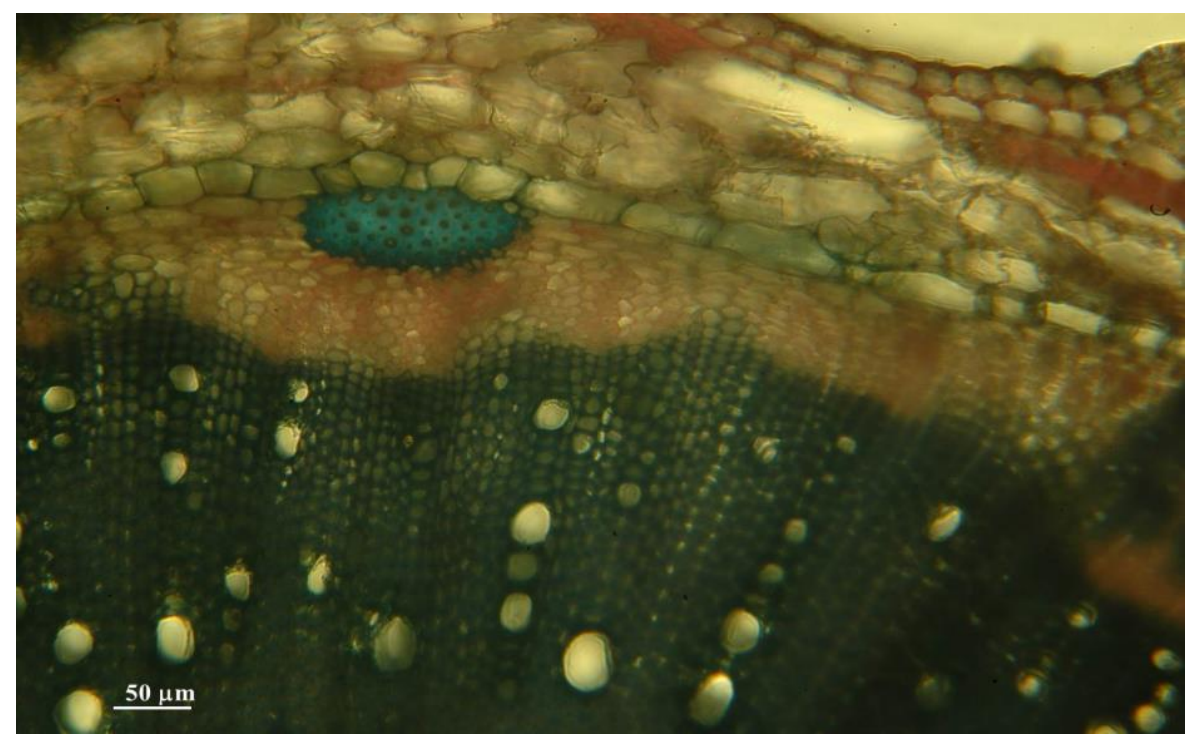

Fig. 10. Symphyotrichum ciliatum, cross section through the median area of the stem highlighting the epidermis, the bark and the vascular tissues (Iodine Greene \& Carmine Alum, reaction with IIK)

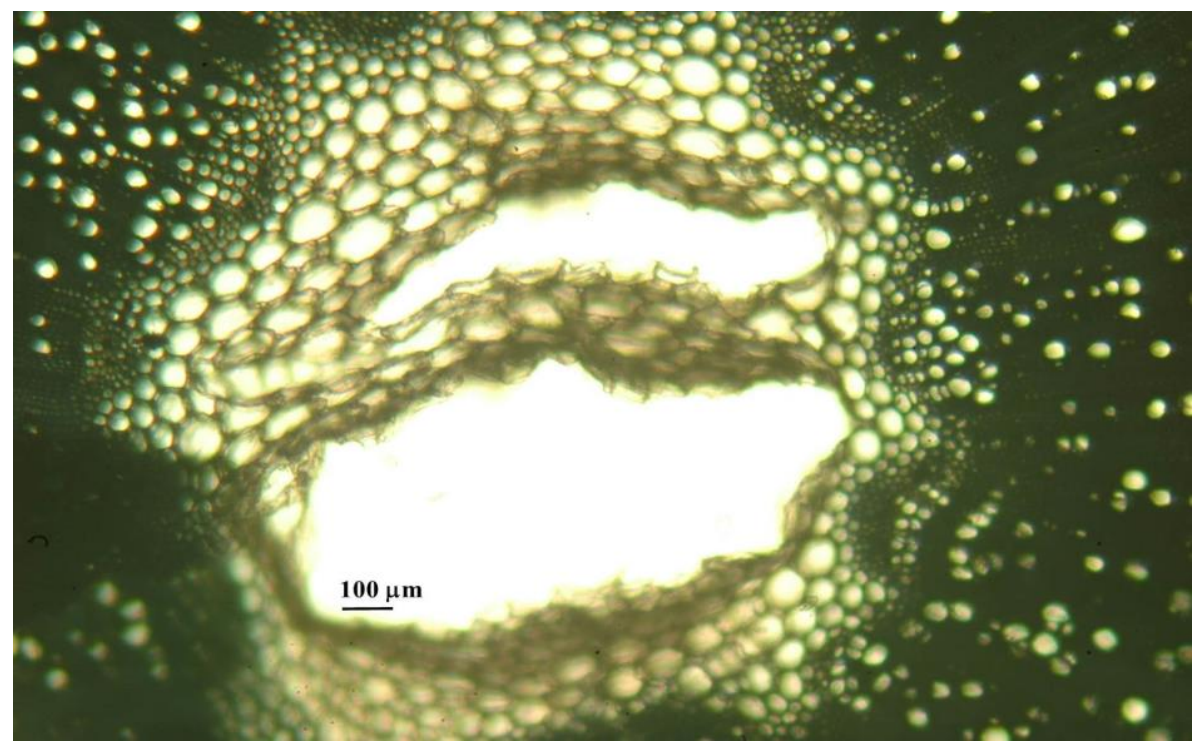

Fig. 11. Symphyotrichum ciliatum, cross section through the median area of the stem highlighting the medullary aeriferous cavities (Iodine Greene \& Carmine Alum) 


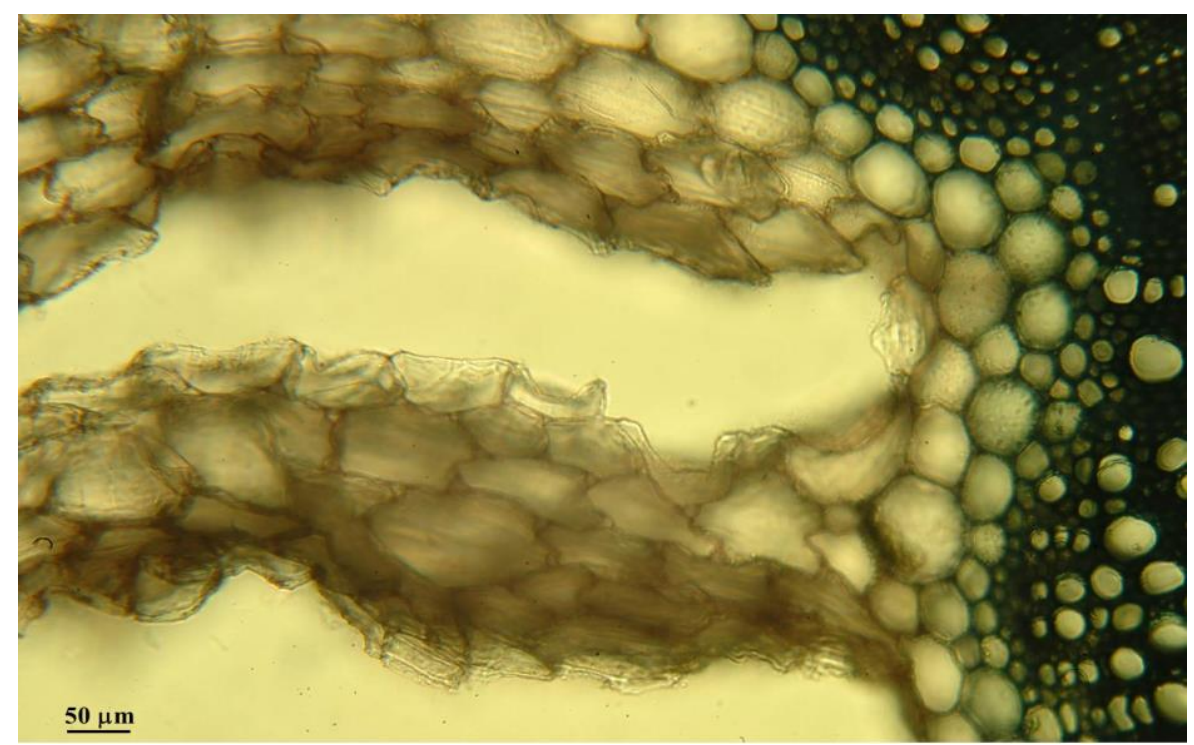

Fig. 12. Symphyotrichum ciliatum, cross section through the median area of the stem highlighting a detail at the level of the medullary aeriferous cavities (Iodine Greene \& Carmine Alum)

Order I Branch. In cross section the contour of the branch is almost circular, with 4-5 ribs separated by vallecules. The coastal area becomes more prominent and the vallecules more visible towards the tip of the stem (Figs 13, 14, 15).

At all three levels of the cross sectioning, the branch displays a fasciculate secondary structure, which resulted from the activity of the vascular cambium.

The epidermis is unistratified, with isodiametric cells covered by a thick cuticle which differentiates prominent cuticular ridges. From place to place there are stomata (anomocytic type) generally displayed at the same level as the other epidermal cells (Fig. 16). The primary bark is parenchymatous with palisade external layers (Figs 17, $18,19)$. The number of palisade layers increased from the base of the branch (one-two) to the top of the branch (four-five). The internal layers of the bark are formed of large cells, more or less isodiametric, and have rare aeriferous meatuses. At the level of the vallecules, especially in the upper third of the branch, there are subepidermal areas of tabulo-angular collenchyma (Fig. 20).

The last layer of the bark is an endodermoid where no accumulation of starch was identified (reaction with IIK). The dimensions of the central cylinder and the thickness of the secondary xylem decrease from the base of the branch to the top. The central cylinder contains 10-12 vascular bundles of different sizes (predominantly large), with a circular disposition (Figs 18, 19, 21). Each bundle presents a periphloemic cap of lignified sclerenchymatous fibres.

The medullary rays are large, formed of cells with thickened and lignified walls at the secondary xylem (Fig. 18). At all the cross sectioning levels the pith is parenchymatous, meatic, made up of large, polygon cells. 


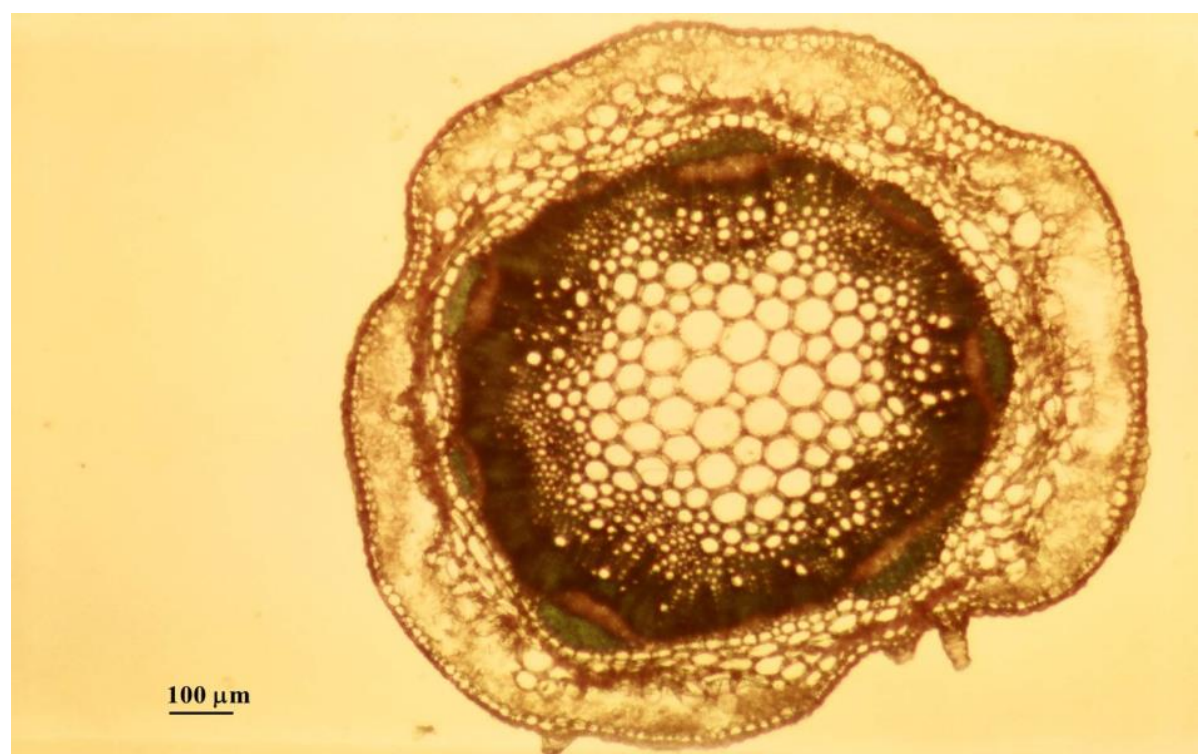

Fig. 13. Symphyotrichum ciliatum, cross section through the Order I branch, in the base area (Iodine Greene \& Carmine Alum)

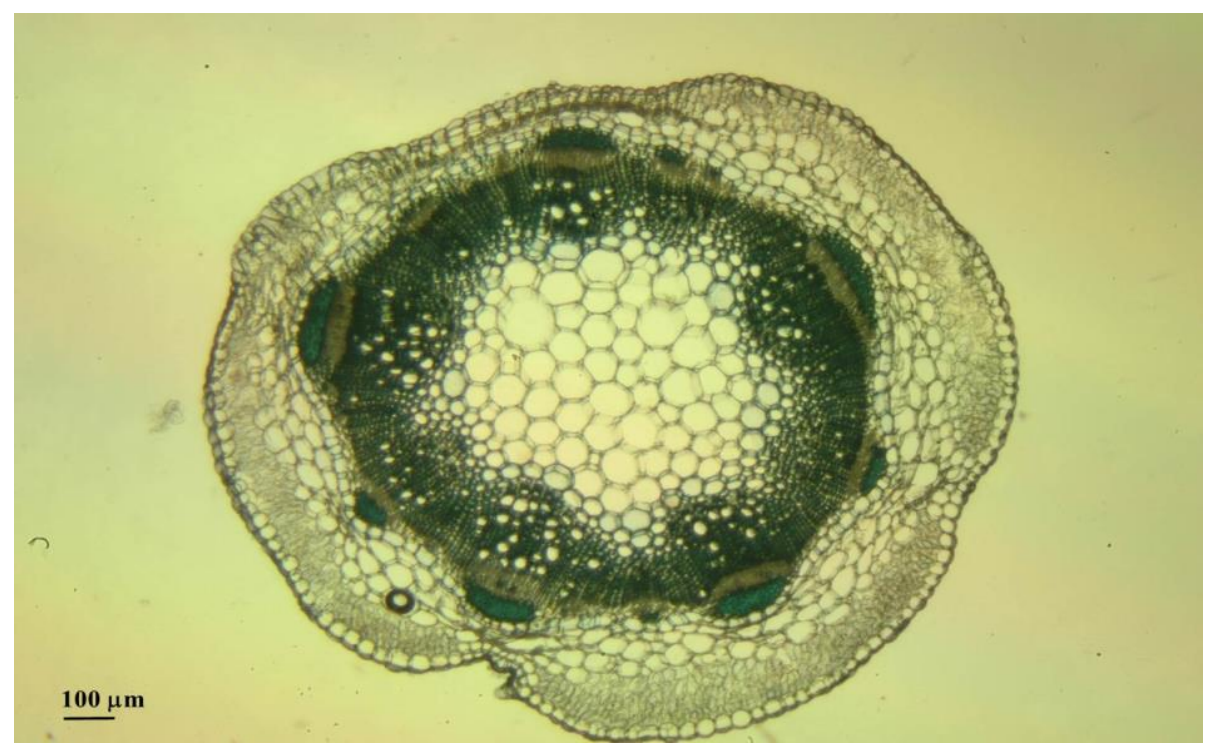

Fig. 14. Symphyotrichum ciliatum, cross section through the Order I branch, in the median area (Iodine Greene \& Carmine Alum) 


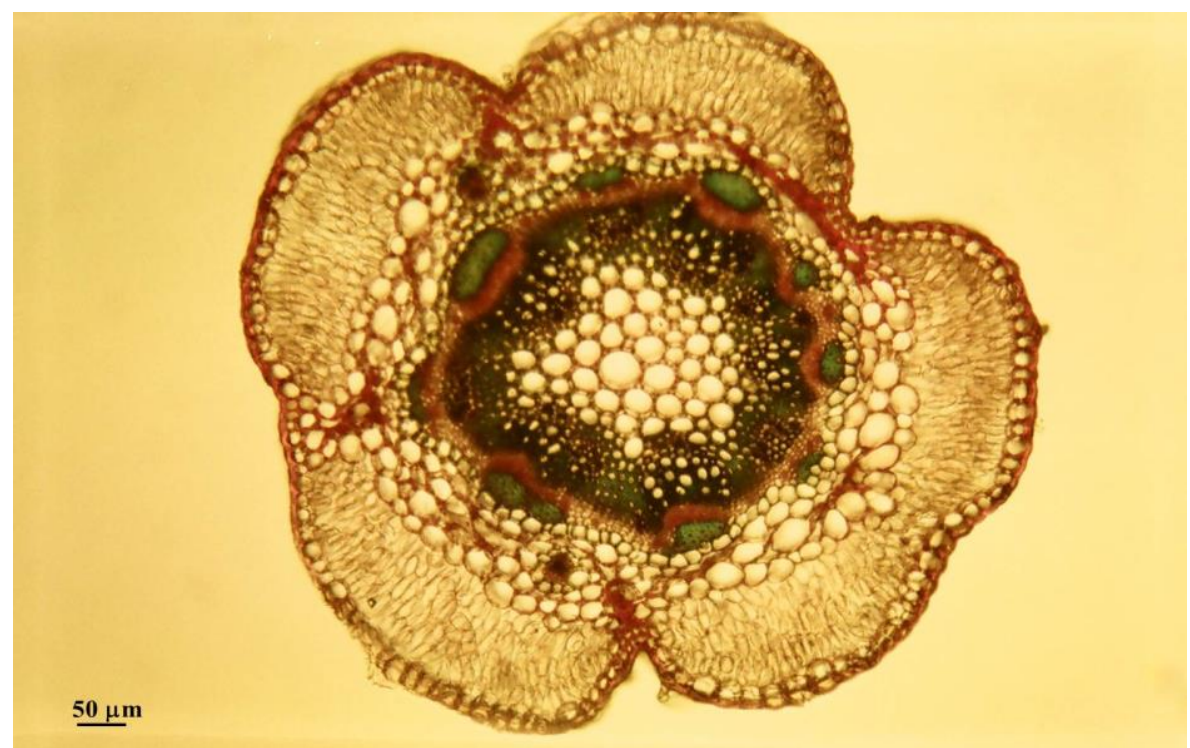

Fig. 15. Symphyotrichum ciliatum, cross section through the Order I branch, in the apical area (Iodine Greene \& Carmine Alum)

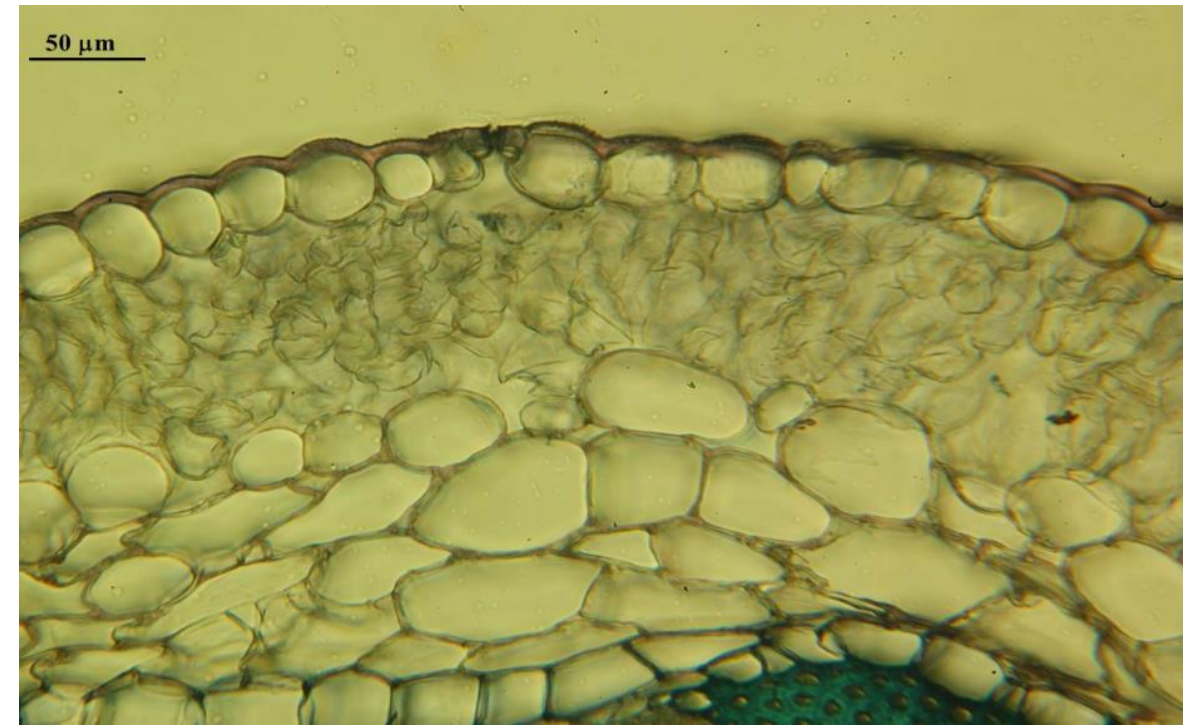

Fig. 16. Symphyotrichum ciliatum, cross section through the Order I branch, in the median area, highlighting the epidermis and the bark (Iodine Greene \& Carmine Alum) 


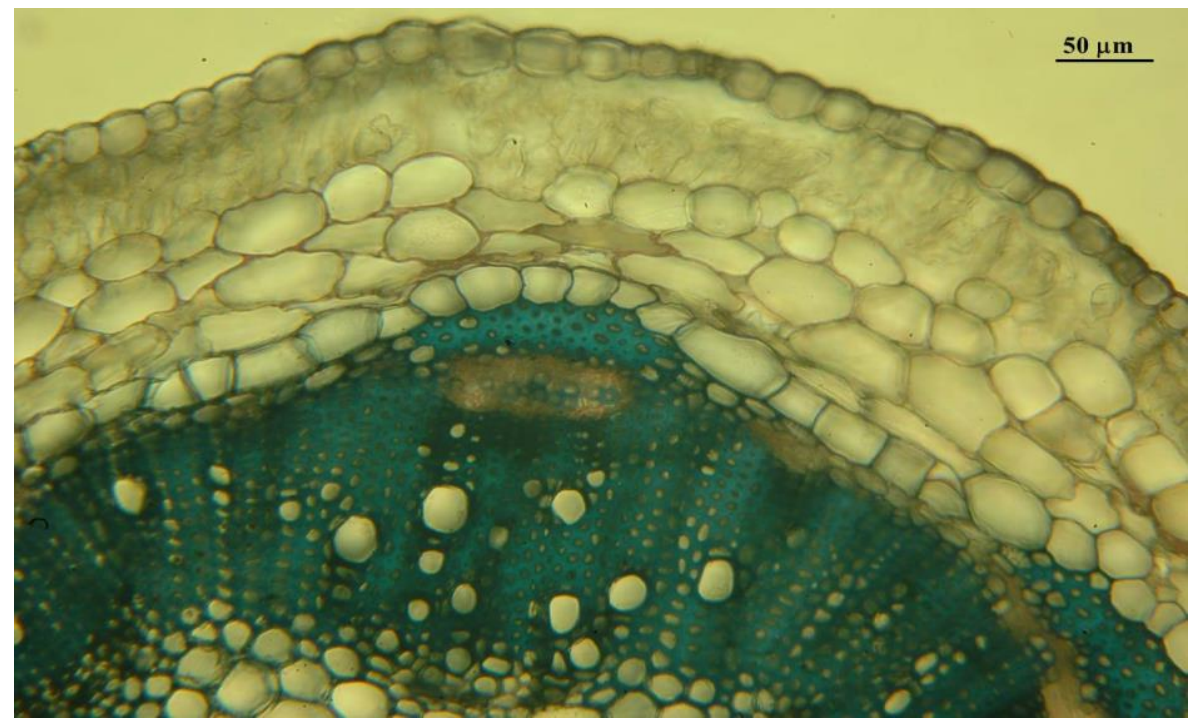

Fig. 17. Symphyotrichum ciliatum, cross section through the Order I branch, in the base area, highlighting the epidermis, bark and vascular tissues (Iodine Greene \& Carmine Alum)

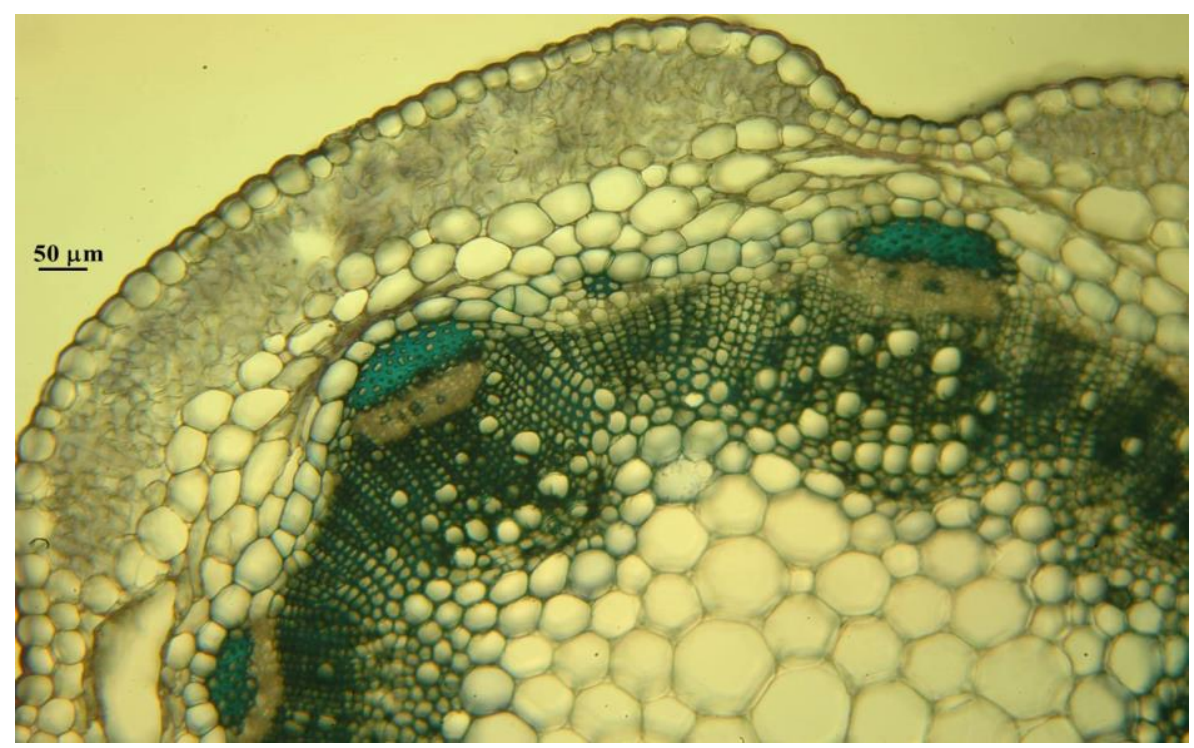

Fig. 18. Symphyotrichum ciliatum, cross section through the Order I branch, in the median area, highlighting the epidermis, bark and central cylinder (Iodine Greene \& Carmine Alum) 


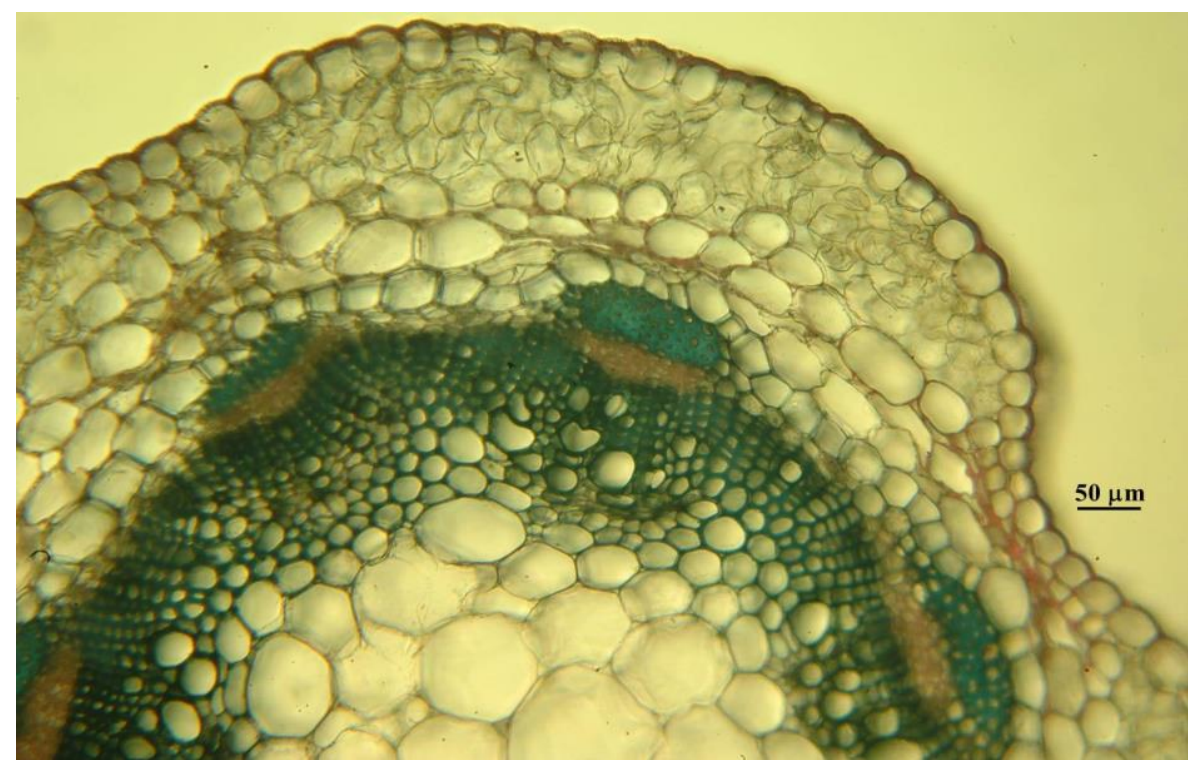

Fig. 19. Symphyotrichum ciliatum, cross section through the Order I branch, in the apical area, highlighting the epidermis, bark and the central cylinder (Iodine Greene \& Carmine Alum)

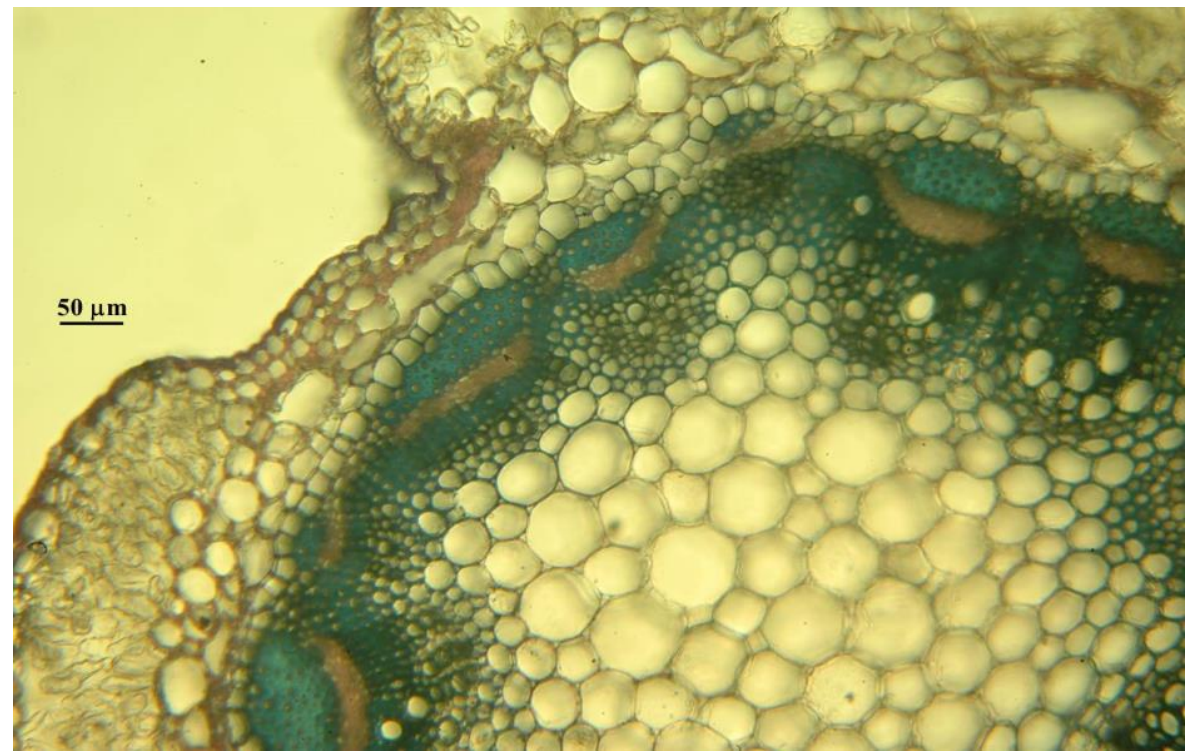

Fig. 20. Symphyotrichum ciliatum, cross section through the Order 1 branch, in the apical area, highlighting the epidermis, bark and central cylinder (Iodine Greene \& Carmine Alum) 


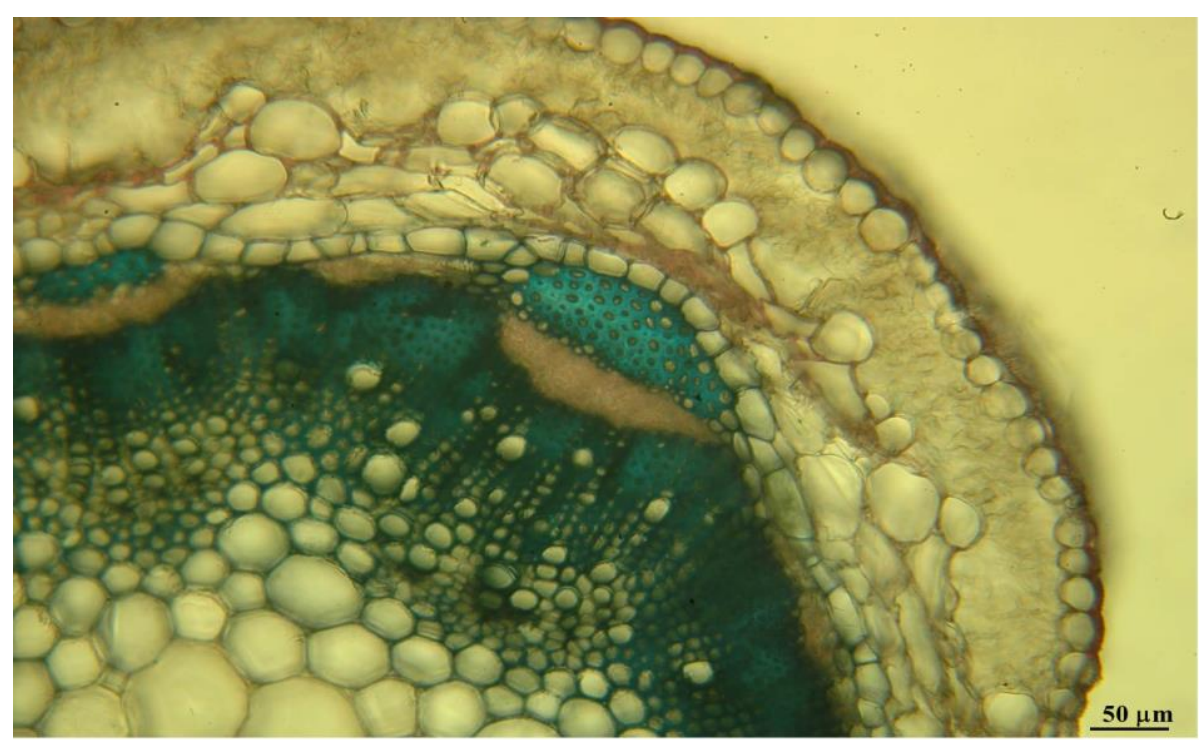

Fig. 21. Symphyotrichum ciliatum, cross section through the Order I branch at the base, highlighting the epidermis, bark and the central cylinder (Iodine Greene \& Carmine Alum)

The lamina. In the lower and median third of the lamina, the contour of the cross section is semi-circular with a flat adaxial face (Fig. 22). In the upper third, the lamina has an elongated, eliptic contour with both sides flat.

At the level of the rounded edges of the lamina there are pluricellular tector hairs (Fig. 23). The epidermis has isodiametric cells, with the external wall thicker than the internal one, and covered by a cuticle with cuticular ridges (Fig. 24).

The lamina is bifacial, amphystomatic, with an ecvifacial structure. The anomocytic stomata are displayed at approximately the same level as the epidermal cells. The mesophyll is formed of two-three layers of palisade cells located under both epidermises and in a narrow central area, formed from relatively isodiametric assimilative cells which leave between them small gaps (dense lacunose tissue) (Fig. 25 ). Around the nervures the palisade cells have a radial disposition.

The vascular tissues form seven closed collateral vascular bundles. The median bundle is the biggest and is slightly prominent at the level of both epidermises through to hypodermal columns formed of large, isodiametric and colourless cells (Fig. 26).

Xylem and phloem vascular elements are present in the structure of all vascular bundles, but are represented in a higher number in the median bundle. Each vascular bundle is surrounded by a parenchymatous, perifascicular sheath, formed of colourless isodiametric cells of various sizes.

Symphyotrichum ciliatum collected on the sands of the Sacalin Island - Danube Delta can be considered a plant of wet and relatively salty places (a meso-hygrohalophyte). According the ecological requirements, Sârbu et al. (2013) already defined Symphiotrichum ciliatum as a meso-hygro-halophyte plant. A series of anatomichistological aspects related to the plant's vegetative organs can be associated with this status. 
In this respect, it is worth noting the presence of the aerenchyma in the structure of the root's primary bark and that of the stem, and also the formation of medullary aeriferous cavities in the median and upper areas of the stem.

Generally hygrophytes form aeriferous tissue in the majority of vegetative organs as an adaptation to the high humidity environment they live in (Toma \& Rugină 1998, Sârbu 1999, Toma \& Gostin 2000, Ciocârlan 2009).

On the other hand, the presence of meatuses and of the periferous gaps in the structure of the primary bark is considered by many authors a feature characteristic to halophilic plants. As such this characteristic has been noted in other halophytes such as Aster tripolium L. (meso-hygrohalophyte up to hygrohalophyte) and Juncus gerardii Loisel. (meso-hygrohalophyte) (Grigore \& Toma 2010).

Another structural aspect that sustains the preference of this plant for salty soils is the presence in the structure of the lamina of some elements with a role in storing water (aquiferous), represented by the large and colourless parenchymatous cells from the structure of the hypodermal columns located around the median nervures, and also by those of the perifascicular sheaths. Such elements involved in the water economy of halophile plants have also been reported in other Asteraceae plants such as Aster tripolium L. and Artemisia santonicum L. (xero-mesophyte, halophyte) (Grigore et al. 2014).

The results presented in this paper confirm the ecologic status of Symphyotrichum ciliatum as a meso-hygro-halophyte plant.

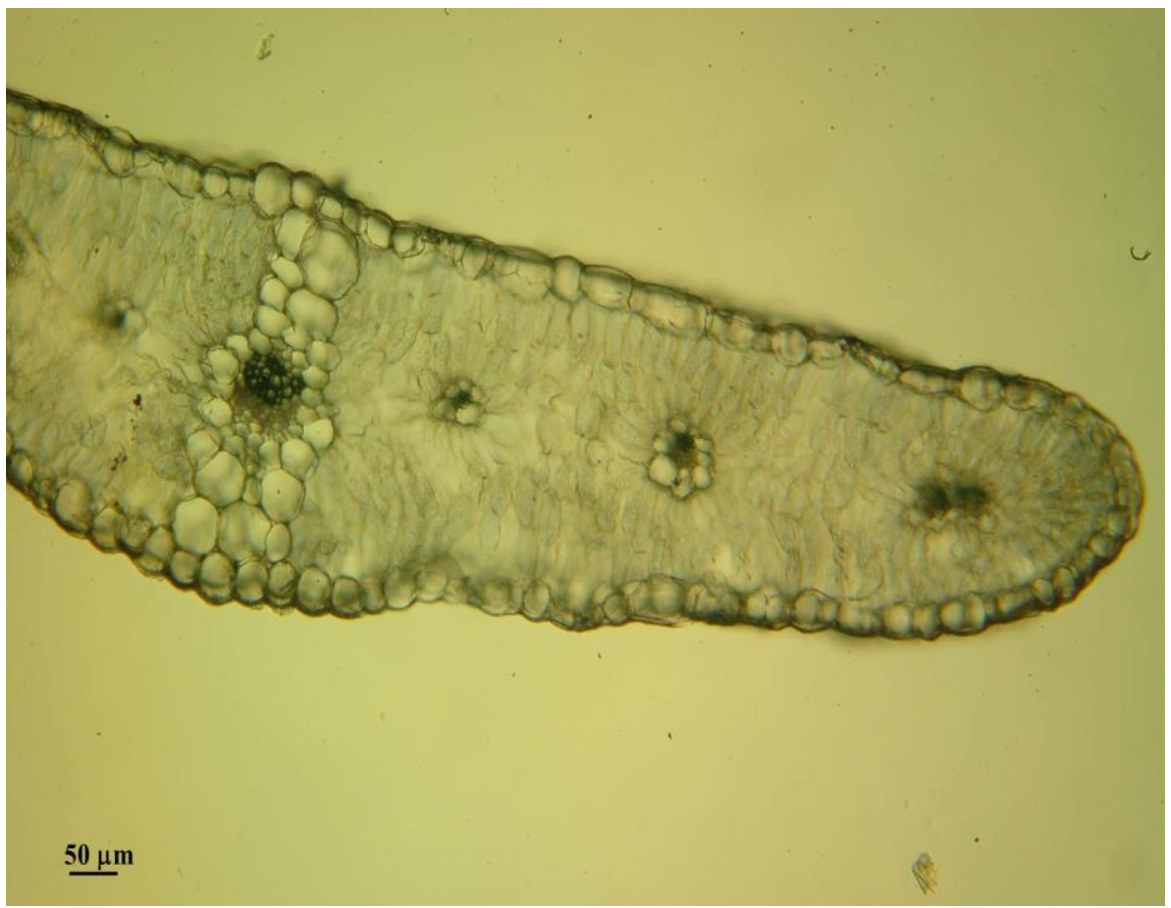

Fig. 22. Symphyotrichum ciliatum, cross section through the lamina, in the median third (Iodine Green \& Carmine Alum) 


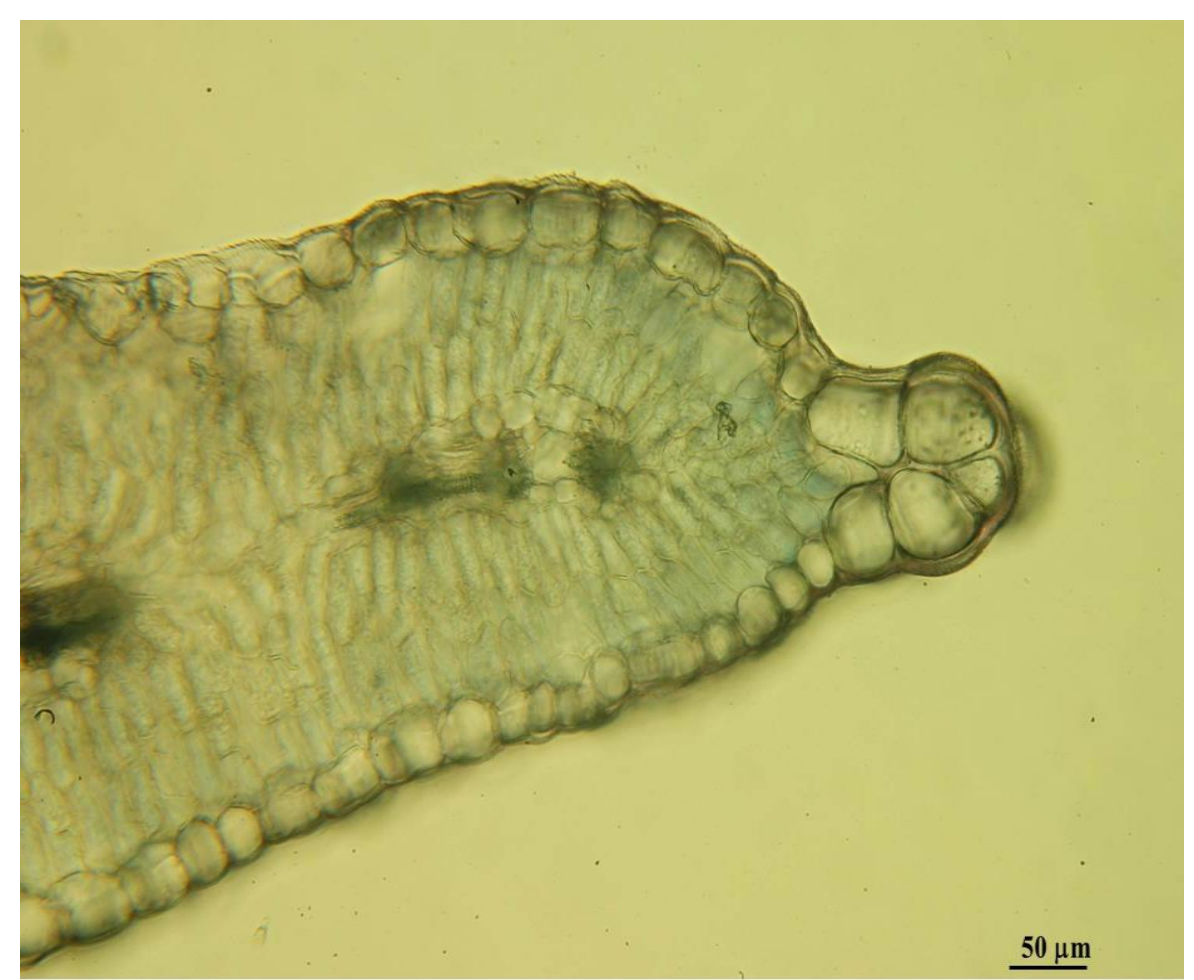

Fig. 23. Symphyotrichum ciliatum, cross section through the lamina, in the median third, highlighting the formation of a tector hair (Iodine Green \& Carmine Alum)

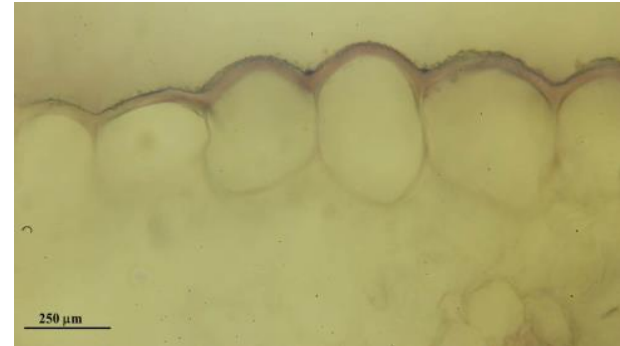

Fig. 24. Symphyotrichum ciliatum, cross section through the lamina, in the median third, highlighting the lower epidermis cells (Iodine Green \& Carmine Alum)

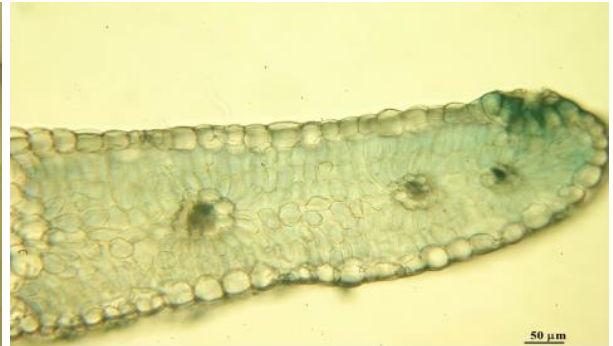

Fig. 25. Symphyotrichum ciliatum, cross section through the lamina, in the median third, highlighting the lamina's ecvifacial structure (Iodine Green \& Carmine Alum) 


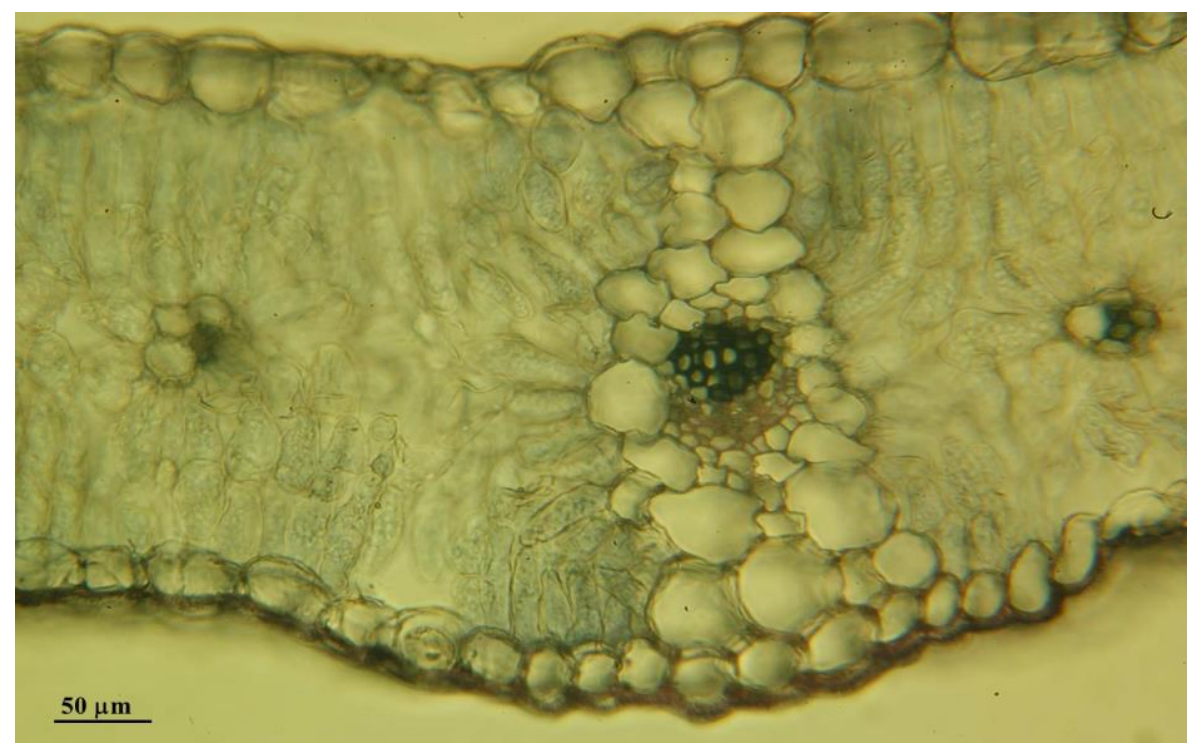

Fig. 26. Symphyotrichum ciliatum, cross section through the lamina, in the median third, highlighting the median nervure (Iodine Green \& Carmine Alum)

\section{Conclusion}

Symphyotrichum ciliatum is an invasive adventive plant, spread across many areas in Romania, more often on relatively wet soils and lightly salted.

The structural characteristics of the vegetative body of the plant analysed in the current paper document the ecological preference of this species, and support the great capacity for spreading of the taxon.

Symphyotrichum ciliatum has at the level of the vegetative organs a particular structure for an annual plant, which enables it to constitute a robust vegetative body well adapted to the environment. In this respect the root, the stem and the branches differentiate a secondary structure, and the ecvifacial bifacial structure of the lamina provides efficiency in capturing the light, especially on sands where light is reflected.

Symphyotrichum ciliatum is a meso-hygrophyte and halophyte, well adapted to the conditions of the wet, salty soils. In this respect, the plant has aeriferous formations at the level of the root and stem, and aquiferous formations at the level of the lamina.

The robust structure of the vegetative body and its adaptations to the environment of wet and salt areas confirm the fact that this plant, already considered invasive in Romania, can have a significant impact over the vegetal communities where they grow, becoming a real danger for coastal habitats.

\section{References}

Anastasiu, P. (2010). Contributions to chorological data on Romanian Flora. Acta Horti Bot. Bucurest., 37, 45-50.

Anastasiu, P. \& Negrean, G. (2007). Invadatori vegetali în România. Bucureşti: Edit. Universităţii din Bucureşti. 
Beldie, A. \& Váczy, C. (1976). Capitolul 3. - Taxoni noi pentru flora României, publicați după editarea volumelor respective din "Flora R.S.R.”. In T. Săvulescu (ed.), Flora României. Vol. 13 (pp. 35-53). București: Edit. Academiei Române.

Chocholoušková, Z. \& Pyšek, P. (2003). Changes in composition and structure of urban flora over 120 years: a case study of city of Plzeň. Flora, 198, 366-376.

Ciocârlan, V. (1994). Flora Deltei Dunării. București: Edit. Ceres.

Ciocârlan, V. (2009). Flora ilustrată a României. Pteridophyta et Spermatophyta. Ed. III. Bucureşti: Edit. Ceres.

Filipaş, L. \& Cristea, V. (2006). New "guests" among cormophyte species of ClujNapoca. Contrib. Bot. Cluj, 41(2), 17-21.

Grigore, M.N. \& Toma, C. (2010). Halofitele - Aspecte de anatomie ecologică. Iaşi: Edit. Universității "Al. I. Cuza".

Grigore, M.N., Ivănescu, L. \& Toma, C. (2014). Halophytes: An Integrative Anatomical Study. Springer International Publishing.

McKinney, M.L. (2006). Urbanization as a major cause of biotic homogenization. Biological conservation, 127, 247-260.

Popescu, A. \& Sanda, V. (1998). Conspectul florei cormofitelor spontane din România. Acta Bot. Horti Bucurest., /1998/, 3-336.

Sârbu, A. (1999). Biologie vegetală. Bucureşti: Edit. Universităţii din Bucureşti.

Sârbu, I., Ştefan, N., Ivănescu, L. \& Mânzu, C. (2001). Flora ilustrată a plantelor vasculare din estul României. Vol. II. Iaşi: Edit. Univ. "Al. I. Cuza".

Sârbu, I., Ştefan, N. \& Oprea, A. (2013). Plante vasculare din România. Determinator ilustrat de teren. București: Edit. Victor B Victor.

Sîrbu, C., Ferus, P., Elias, JR.P., Samuil, C. \& Oprea, A. (2015). Symphyotrichum ciliatum in Romania: trends of spread and invaded plant communities. Open Life Sci., 10, 159-176.

Sîrbu, C. (coord.) \& Oprea, A. (2011). Plante adventive în flora României. Iaşi: Edit. "Ion Ionescu de la Brad".

Şerbănescu-Jitariu, G., Andrei, M., Rădulescu-Mitroiu, N. \& Petria, E. (1983). Practicum de biologie vegetală. Bucureşti: Edit. Ceres.

Ştefan, N. (1980). Cercetarea florei şi vegetației din bazinul superior şi mijlociu al râului Râmnicu Sărat. PhD Thesis. Universitatea "A.I.Cuza”, Iaşi.

Toma, C. \& Gostin, I. (2000). Histologie vegetală. Iaşi: Edit. Junimea.

Toma, C. \& Rugină, R. (1998). Anatomia plantelor medicinale. Atlas. Bucureşti: Edit. Academiei Române. 